\title{
Streaming flow of an Antarctic Peninsula palaeo-ice stream, both by basal sliding and deformation of substrate
}

\author{
Benedict T.I. REINARDY, ${ }^{1}$ Robert D. LARTER, ${ }^{2}$ Claus-Dieter HILLENBRAND, ${ }^{2}$ \\ Tavi MURRAY, ${ }^{1}$ John F. HIEMSTRA, ${ }^{1}$ Adam D. BOOTH ${ }^{1}$ \\ ${ }^{1}$ Department of Geography, Swansea University, Singleton Park, Swansea SA2 8PP, UK \\ E-mail: 371404@swansea.ac.uk \\ ${ }^{2}$ British Antarctic Survey, Natural Environment Research Council, Madingley Road, Cambridge CB3 OET, UK
}

\begin{abstract}
Acoustic sub-bottom profiler surveys on the northeast Antarctic Peninsula shelf indicate that parts of the seabed are underlain by an acoustically transparent layer that is thin on the inner shelf and becomes thicker and more extensive towards the outer shelf. Sedimentological and geophysical data are combined to construct a bed model where streaming ice flow, by both deformation and basal sliding, took place within cross-shelf troughs. The model suggests only limited deformation contributed to fast flow on the inner shelf, i.e. in the onset zone of ice streaming, where the bed was predominantly underlain by a stiff till. Thus, fast ice flow in this area might have been by basal sliding, with deformation confined to discontinuous patches of soft till $<40 \mathrm{~cm}$ thick. Towards the middle and outer shelf, extensive, thick sequences of soft till suggest a change in the dominant subglacial process towards widespread deformation. This downstream change from basal sliding to subglacial deformation is manifest in the transition from stiff-till dominance to soft-till dominance, while a downstream increase in ice flow velocity is evident from the complex geomorphic imprint on the inner shelf evolving to the more restricted set of bedforms on the outer shelf.
\end{abstract}

\section{INTRODUCTION}

Ice streams are fast-flowing (hundreds to thousands of metres per year) linear features up to hundreds of kilometres long and tens of kilometres wide, set within slower-moving ice (Bentley, 1987; Bennett, 2003). Bennett (2003) estimates that $90 \%$ of all ice and sediment discharged by the Antarctic ice sheet today flows within its ice streams. As a consequence, they play a key role in the mass balance and dynamic behaviour of past and present ice sheets. Fast ice flow, or 'ice streaming', occurs either by deformation of soft substrate (i.e. deforming till) or by basal sliding across the bed. However, the temporal and spatial variability of these processes is still open to much debate. Initial seismic and borehole studies on the Siple Coast ice streams in West Antarctica indicated the presence of a deforming till that in some situations has been estimated to account for $80-90 \%$ of rapid ice flow (Alley and others, 1986; Blankenship and others, 1986; Engelhardt and others, 1990). However, this association was later challenged when further borehole studies suggested basal sliding accounted for a similar amount of rapid ice flow, with deformation confined to just a few centimetres at the surface of the subglacial sediment (Engelhardt and Kamb, 1998; Kamb, 2001). Whichever process is dominant potentially affects an ice stream's dynamics, and is likely to be reflected in the morphology and character of the subglacial sediments left behind after deglaciation (Smith and Murray, 2009). Few studies have managed to access the bed of a contemporary ice stream (e.g. Engelhardt and others, 1990; Engelhardt and Kamb, 1998). In comparison, accessing subglacial sediments of palaeo-ice streams provides an opportunity to study their basal environments unimpeded (Stokes and Clark, 2001). The major advantage of the marine ice-stream record on previously glaciated shelves is that it is relatively undisturbed, with mega-scale glacial lineations (MSGLs) that can be traced occasionally up to hundreds of kilometres (e.g. Canals and others, 2000; Ó Cofaigh and others, 2005).
The discovery of deep troughs across the northeast Antarctic Peninsula (NEAP) shelf in the early 1990s (Anderson, 1992; Sloan and others, 1995), the recovery of sediments interpreted as subglacial tills and seismic reflection profiles with extensive unconformities at depths far below late Quaternary sea-level low-stands were the first indicators that the Antarctic Peninsula ice sheet (APIS) had advanced to the shelf edge in the past, with ice flow and drainage focused within these troughs similar to the western side of the Antarctic Peninsula (e.g. Larter and Barker, 1989; Larter and Vanneste, 1995; Canals and others, 2000; Heroy and Anderson, 2005 and references therein; Anderson and Oakes-Fretwell, 2008). The first detailed geophysical surveys of the inner shelf following the collapse of the Larsen A and $B$ ice shelves led to the discovery of numerous streamlined bedforms within the troughs (Pudsey and others, 2001; Gilbert and others, 2003; Domack and others, 2005; Evans and others, 2005). It seems that, regionally, fast-flowing ice streams were important glacio-dynamic features on both the eastern and western margin of the APIS during the last glacial cycle, and played a significant role in controlling both the behaviour and stability of the ice sheet (Evans and others, 2005; Ó Cofaigh and others, 2005).

Previous models of ice flow on the NEAP shelf suggested that a low-shear-strength ('soft') till, which is mainly limited to the cross-shelf troughs and interpreted as deformation till, facilitated streaming flow (Evans and others, 2005; Ó Cofaigh and others, 2007). Swath bathymetric surveys revealed streamlined bedforms and MSGLs documenting the former presence of ice streams within these troughs (Camerlenghi and others, 2001; Gilbert and others, 2003; Evans and others, 2005; Heroy and Anderson, 2005). Evans and others (2005) also implied that in small, localized areas on the NEAP shelf the palaeo-ice streams may have flowed over relatively higher-shear-strength ('stiff') till, although the authors did not discuss the processes involved. This evolution of basal 


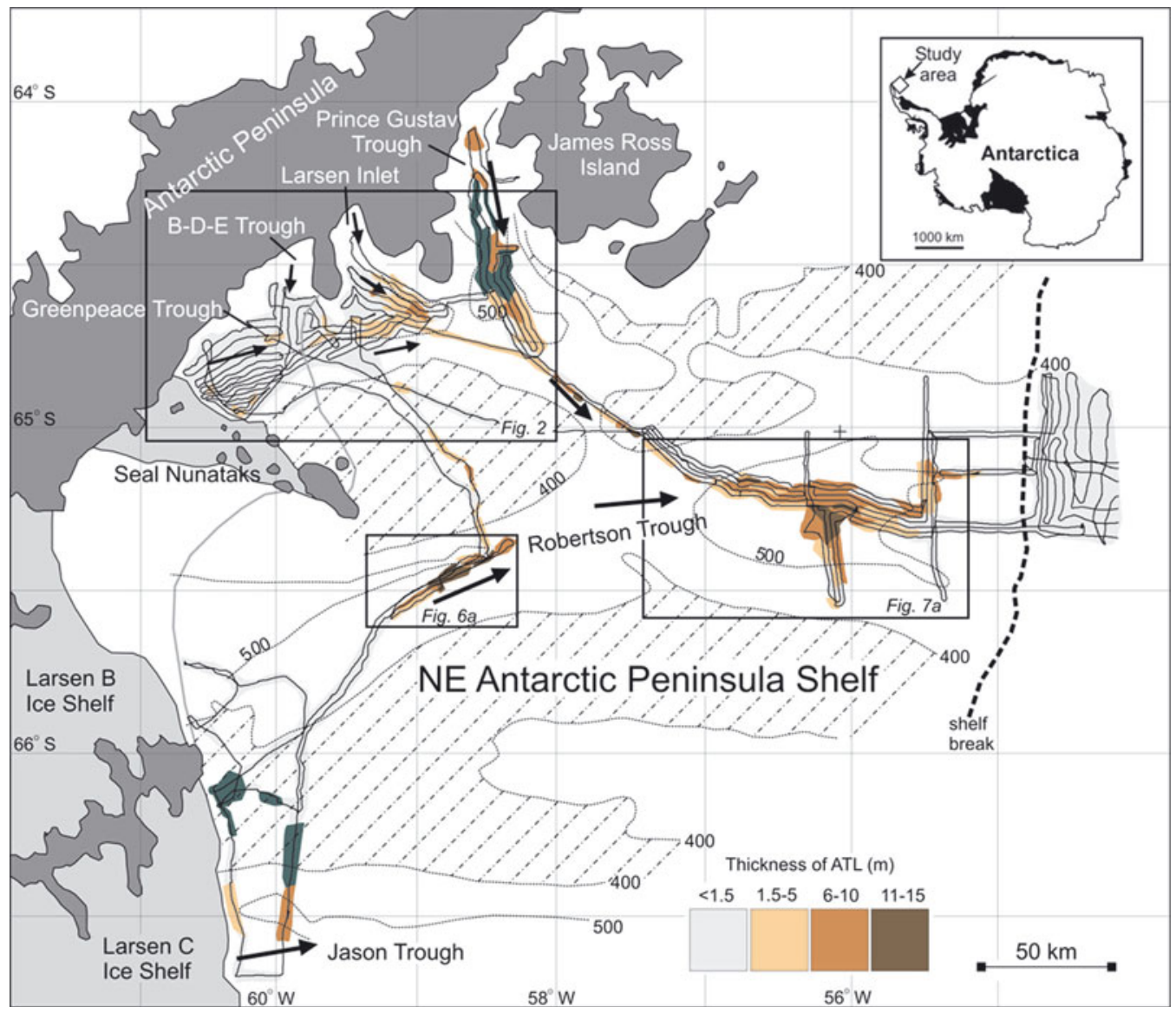

Fig. 1. Map of the study area east of the Antarctic Peninsula showing the geography of the region and bathymetry of the shelf (in metres water depth taken from Evans and others, 2005). Hatching indicates areas of the shelf shallower than $400 \mathrm{~m}$, and thick black dashed line indicates shelf edge. Light grey line indicates extent of the former Larsen A ice shelf in 1992 from Bindschadler and others (1994) and former Larsen B ice shelf in 2000 from Cook and Vaughan (2010), and light grey shading indicates areas still covered by an ice shelf. Solid black lines indicate JR71 ship track and survey area; JR48 ship track is not included but covered the same area as JR71 in Greenpeace Trough and Prince Gustav Channel. Boxed areas on the map refer to detailed EM120 swath bathymetric maps in Figures 2, 6a and 7a. Overlaid on the bathymetric map is thickness of ATL calculated from the Topographic Parametric Sonar (TOPAS) and $3.5 \mathrm{kHz}$ data. At a few locations, the ATL is thicker than $15 \mathrm{~m}$, but these areas are laterally discontinuous. Areas marked in green contain an ATL, but a combination of geophysical data and sedimentological data from cores indicates that the corresponding ATL does not relate to a subglacial soft till. Black arrows indicate palaeo-ice flow directions interpreted from streamlined bedforms (Evans and others, 2005).

conditions has also been observed under contemporary ice streams (e.g. Peters and others 2007; Joughin and others, 2009) and elsewhere in the palaeo-record (e.g. Graham and others 2009; Larter and others, 2009).

Here we use geophysical survey data together with sedimentological information from cores recovered on the NEAP shelf to identify the underlying strata of the shelf and to gain detailed information on the thickness and geographical distribution of an acoustically transparent layer (ATL) directly below the sea-floor. This ATL corresponds to the soft till recovered in sediment cores, which was deposited within several cross-shelf troughs during the last glacial period. We present and use a conceptual model for evaluating the degree to which overlying ice flowed by basal sliding or sediment deformation from the inner to the outer shelf. We also assess the relationship between till distribution and the geomorphology of the seabed.

\subsection{Physiographic setting}

Prince Gustav Trough and Greenpeace Trough are two large glacial troughs with water depths in excess of $500 \mathrm{~m}$ on the inner shelf of the NEAP (Fig. 1) (Anderson, 1992; Sloan and others, 1995; Evans and others, 2005). Smaller troughs in
Larsen Inlet and further south at the terminus of Bombardier, Dinsmoor and Edgemoor glaciers (B-D-E Trough) join up with Greenpeace Trough from the northwest (del Valle and others, 1998; Pudsey and others, 2001). For simplicity, we refer to the inner shelf area covered by three of these troughs (excluding Prince Gustav Trough) as the Larsen A shelf, as it was formerly covered by the Larsen A ice shelf west of $59^{\circ} \mathrm{W}$. The Prince Gustav and Larsen A shelf troughs coalesce and connect into the larger Robertson Trough which extends from the Larsen B ice shelf to the outer shelf. Further to the south, Jason Trough runs parallel to Robertson Trough and seems to extend east from the Larsen $C$ ice shelf towards the shelf edge, although there are only limited survey data from this area.

Interpretations of the sedimentary sequences recovered from the NEAP shelf have previously been published (Reinardy and others, 2009 and references therein). Essentially, the cores recovered up to four stratigraphic units: unit 1 is a diamicton with high shear strength $(25-100 \mathrm{kPa})$ at the bottom of the cores, interpreted as a subglacial till (the 'stiff' till; Evans and others, 2005); unit 2 is a low-shear-strength diamicton $(<12 \mathrm{kPa}$, but mainly $<5 \mathrm{kPa})$, again interpreted as a subglacial till (the 'soft' till; Evans and others, 2005); unit 3 


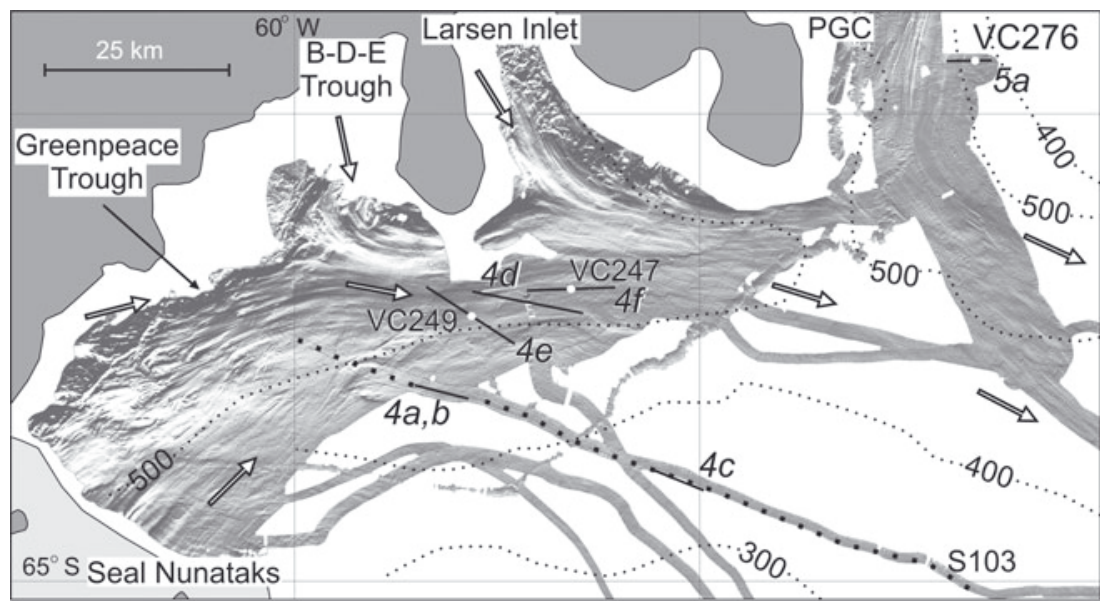

Fig. 2. EM120 shaded relief image (gridcell size $50 \mathrm{~m} \times 50 \mathrm{~m}$ ), illuminated from the northwest, projected in Mercator (World Geodetic System 1984 ellipsoid (WGS84)) modified from Evans and others (2005) (see Fig. 1 for location). Contours indicate water depth (m). White arrows indicate former ice-flow direction. Black lines indicate locations of TOPAS profiles, with white dots indicating core locations, bold black dotted line indicating seismic line S103 and figure numbers indicated in italics.

is a transitional heterogeneous unit interpreted as representing a sub-ice-shelf deposit proximal to the grounding line; and unit 4 comprises an upper diatom-bearing mud interpreted as a postglacial drape deposited after further retreat of the grounding line in either a distal, sub-ice-shelf environment or under seasonal open marine conditions.

\section{METHODS}

Geophysical surveys of the NEAP shelf were carried out during cruises JR48 (in 2000) and JR71 (in 2002) on the RRS James Clark Ross. Navigation data were acquired using differential GPS. During cruise JR48, a precision echo sounder and $3.5 \mathrm{kHz}$ profiler were used. Both instruments were run using hull-mounted transducers. The precision echo sounder signal was output to a Waverley thermal linescan recorder, and the $3.5 \mathrm{kHz}$ signal was output to a Raytheon electrostatic line-scan recorder. The $3.5 \mathrm{kHz}$ signal was not recorded in any other way, so post-cruise replay of the data is not possible.

During cruise JR71, a single-channel seismic reflection profile on the inner continental shelf (line S103) was acquired (Fig. 2). The seismic source was a Bolt 600B array of four $40 \mathrm{in}^{3}$ airguns with wave shape kit, and a $30 \mathrm{~m}$ Services et Instruments Géophysique hydrophone streamer was used as the receiver, with the output from all hydrophones summed into a single trace. Multi-beam swath bathymetry and acoustic sub-bottom profiler data were collected using a hull-mounted Kongsberg-Simrad EM120 system and a Topographic Parametric Sonar (TOPAS) system, respectively. The EM120 system emits 191 beams, each with dimensions of $1^{\circ} \times 1^{\circ}$, with frequencies in the range $11.25-12.75 \mathrm{kHz}$ and a maximum port- and starboard-side angle of $75^{\circ}$. In practice, the system is typically run with maximum port- and starboard-side angles of $68^{\circ}$, which, in water depths of $\sim 500 \mathrm{~m}$, is equivalent to a total swath width of $\sim 2.5 \mathrm{~km}$. This system allows mapping of the sea-floor with vertical and horizontal uncertainties of 1 and $5 \mathrm{~m}$, respectively. Beam ray paths and sea-floor depths were calculated in near real time using sound velocity profiles derived from expendable bathythermograph casts and assuming that salinity did not vary with depth. Anomalous values were removed and data were then gridded at cell sizes of $30-50 \mathrm{~m}$. Bedforms were digitized from the swath bathymetry images.

The TOPAS acoustic profiler uses parametric interference between two primary transmission frequencies to produce a narrow $\left(5^{\circ}\right.$ ) beam with user-specified secondary frequencies in the range $0.5-5 \mathrm{kHz}$. In our study area, a 'burst' source was used consisting of two cycles of a secondary frequency of $2.8 \mathrm{kHz}$. Reflected TOPAS signals were recorded digitally with a sampling rate of $10 \mathrm{kHz}$. The TOPAS system is able to profile the sub-sea-floor at a high depth resolution $(\sim 0.5 \mathrm{~m})$ with penetration dependent on the nature of the substrate. Fine-grained sediments can be imaged to greater depth ( $>100 \mathrm{~m}$ penetration can be achieved) than coarser-grained and poorly sorted deposits (typically $<40 \mathrm{~m}$ ) (Evans and others, 2005; Ó Cofaigh and others, 2007). During the survey of the NEAP shelf, TOPAS generally penetrated sediments to depths of $1.5-30 \mathrm{~m}$. A sonic velocity of $1600 \mathrm{~m} \mathrm{~s}^{-1}$ was measured for soft till layers in some of the cores using a multisensor core logger (discussed later) and is assumed for other areas of the bed displaying an ATL. This value is compatible with seismic velocities suggested for till layers below modern West Antarctic ice streams (Blankenship and others, 1986). The TOPAS data were used to identify the areas with a subbottom reflector and ATL. The thickness of the ATL was then used to correlate the acoustic stratigraphy to the corresponding sedimentary stratigraphy recovered within the cores (Fig. 3a and b; Table 1). The pronounced down-core increase in shear strength seen in many cores marks the boundary between the soft and stiff tills, which corresponds to the subbottom reflector seen in TOPAS data (Fig. $3 a$ and b). Thus, the TOPAS data were used to map the lateral extent of various sedimentary units across the shelf. The shear-strength data for the cores were taken from Evans and others (2005), who, using a shear vane, measured shear strength on all cores every $5-10 \mathrm{~cm}$, or where a lithological change occurred.

\section{RESULTS}

One $90 \mathrm{~km}$ seismic line (line S103) was collected during cruise JR71 from the inner Larsen A shelf, trending approximately east-southeast-west-northwest (ESE-WNW) from the 

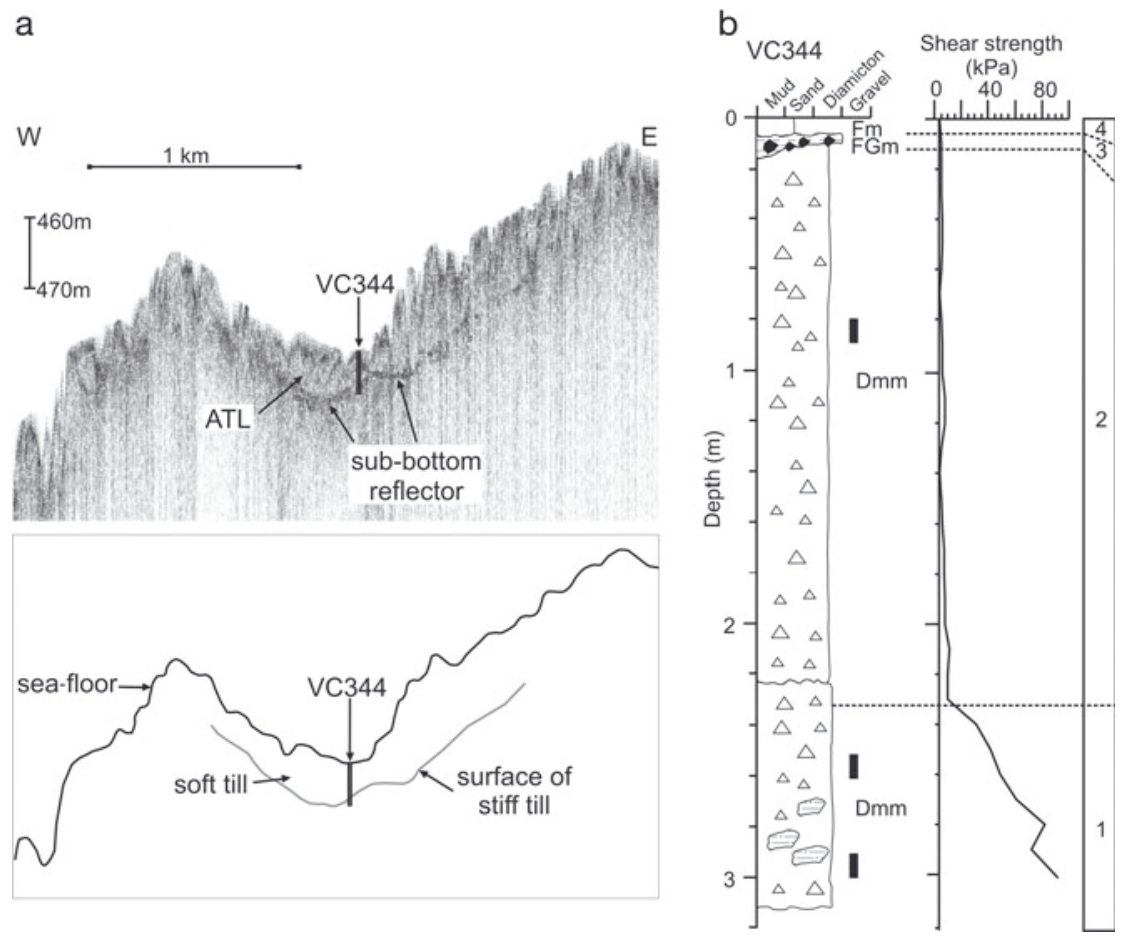

Fig. 3. (a) Detailed image of core site VC344 with top mute applied before sea-floor arrival and annotated schematic illustration (see Fig. 7a for location). The ATL is $\sim 3 \mathrm{~m}$ thick at site VC344 and corresponds to the soft till. (b) Core log of VC344 (after Evans and others, 2005). Dashed lines indicate boundaries between lithological units. Black bars indicate parts of the core that were sampled for micromorphological analysis in Reinardy and others (in press) that confirmed previous interpretations of the diamictons (units 1 and 2) as soft and stiff tills.

shallow bank east of Seal Nunataks into Greenpeace Trough (Figs 2 and 4a). Most of the data are affected considerably by interference from the ship's cathodic protection system, which generated electrical noise at $100 \mathrm{~Hz}$, within the range of frequencies used to interpret geological structures. Furthermore, the data contain bubble-pulse reverberations with a period of $100 \mathrm{~ms}$. A notch-filter of $95-105 \mathrm{~Hz}$ removed most of the noise but also reduced a significant part of the desired signal. However, it is still possible to recognize reflectors dipping at $2.5-6.5^{\circ}$ to the east that can be traced to within $10 \mathrm{~m}$ of the sea-floor (Fig. 4a). Importantly, there is no evidence for any significant change in seismic stratigraphy along the survey line. The corresponding $3.5 \mathrm{kHz}$ and TOPAS sub-bottom profiles show a hard seabed with $<2 \mathrm{~m}$ of sediment that presumably overlies the dipping reflectors observed in the seismic profile (Fig. 4b). Figure 1 shows the distribution of the ATL interpreted from TOPAS data collected along the ship tracks of JR48 and JR71. Some parts of the inner shelf sea-floor show isolated patches of sediment that attain thicknesses of 4-5 $\mathrm{m}$ (Figs 1 and $4 \mathrm{c}$ and d). ATL thicknesses of 4-5 m normally occur either on the tops of ridges or in topographic lows (Fig. 4d). The ATL is rarely observed on the steeper parts of the inner shelf, where it is poorly imaged on the TOPAS data and generally $<1.5 \mathrm{~m}$ thick (Fig. $4 \mathrm{e}$ and $\mathrm{f}$ ). The ATL is generally $<2 \mathrm{~m}$ thick in shallower $(300-400 \mathrm{~m})$ water depth areas between troughs (Fig. 1).

Prince Gustav Trough differs from the rest of the inner shelf in showing a laterally continuous sub-bottom reflector that is smooth and undulating, similar to the sea-floor reflector (Fig. $5 \mathrm{a}$ and b). The thickness of the ATL is generally $<7 \mathrm{~m}$, but decreases to $<5 \mathrm{~m}$ on the steeper trough sides. At the northern end of the Prince Gustav Channel, the ATL increases in thickness up to $11 \mathrm{~m}$ (Fig. 1).
On the mid-shelf within Robertson Trough, including the narrow bathymetric depression linking Greenpeace and Robertson Troughs, the average thickness of the ATL is $5 \mathrm{~m}$ (Fig. 1), although an ATL up to $21 \mathrm{~m}$ thick was observed in one area on the southern trough flank (Fig. 6a and b). On the outer shelf, in the central part of Robertson Trough, the ATL is up to $17.5 \mathrm{~m}$ thick (Fig. 7a and b), but closer to the sides of the trough it is generally only $7-8 \mathrm{~m}$ thick (Figs 1 and $7 \mathrm{c}$ and d). It should be noted that the shallow trough mouth only contains a limited record of an ATL, because it has been scoured extensively by large icebergs as documented by the plough marks on swath bathymetric surveys (Evans and others, 2005, fig. 7e and f; Heroy and Anderson, 2005, fig. $4 \mathrm{~g}$ ) and by the irregular surface reflector in our TOPAS data.

Overall, the ATL is thickest in the central part of the troughs towards the middle to outer shelf (Fig. 1). Here the ATL also corresponds to the thickest soft till layers recovered in sediment cores (Fig. 7c and d; Table 1). In contrast, the sea-floor on the inner shelf is only locally characterized by an ATL, and sediment cores there normally recovered $<0.4 \mathrm{~m}$ of soft till (Fig. $4 \mathrm{e}$ and $\mathrm{f}$ ). The boundary between areas with and without an ATL can be relatively sharp $(<1 \mathrm{~km})$ and typically appears to be orientated parallel to the troughs, i.e. parallel to the former ice-stream flow paths.

\section{INTERPRETATION AND DISCUSSION}

\subsection{Determining homogeneous sedimentary properties of substrate}

Previous models of ice flow on the Antarctic shelf have highlighted the direct link between the locations of geological boundaries within the underlying strata on the shelf and increasing flow velocity (e.g. Wellner and others, 2001, 
Table 1. Lithofacies in cores from the NEAP shelf (after Eyles and others, 1983)

\begin{tabular}{|c|c|}
\hline Lithofacies & Description \\
\hline \multicolumn{2}{|l|}{ Diamict } \\
\hline Dmm & Diamicton, matrix-supported and massive. Clasts are mainly dispersed in silty mud matrix. \\
\hline $\mathrm{Dmm}(\mathrm{s})$ & Diamicton, matrix-supported, weak stratification. Clasts are mainly dispersed in silty mud matrix. \\
\hline $\operatorname{Dmm}(\mathrm{p})$ & $\begin{array}{l}\text { Diamicton, matrix-supported and massive. Clasts are mainly dispersed in silty mud matrix with mm-to } \mathrm{cm} \text {-scale pellets of } \\
\text { silty/clayey mud. }\end{array}$ \\
\hline $\mathrm{Gm}$ & Gravel, massive. \\
\hline GFm & Gravelly mud, massive. \\
\hline GFm(p) & Gravelly mud, massive with $\mathrm{mm}$ - to $\mathrm{cm}$-scale pellets of silty/clayey mud. \\
\hline GFb & Gravelly mud, bioturbated. \\
\hline \multicolumn{2}{|l|}{ Sand } \\
\hline SFm(d) & Sandy mud, massive. Dispersed dropstones. \\
\hline $\operatorname{SFl}(d)$ & Sandy mud, laminated. Laminations are continuous and are contorted by dispersed to clustered gravel-size dropstones. \\
\hline Fm & Mud, massive. \\
\hline $\mathrm{Fm}(\mathrm{d})$ & Mud, bioturbated with dispersed dropstones. \\
\hline $\mathrm{Fb}(\mathrm{d})$ & Mud, massive with dispersed gravel-size dropstones. \\
\hline $\mathrm{Fm}(\mathrm{p})$ & Mud, massive with $\mathrm{mm}$ - to $\mathrm{cm}$-scale pellets of silty/clayey mud. \\
\hline $\mathrm{Pm}$ & Pelletized mud, massive. Abundant mm- to $\mathrm{cm}$-scale pellets of silty/clayey mud. \\
\hline $\operatorname{Pm}(d)$ & Pelletized mud, massive with dispersed dropstones and pellets of silty/clayey mud. \\
\hline
\end{tabular}

2006). This boundary also causes a change from basal sliding to deformation at the ice-stream bed and increasing ice flow velocity. Here we correlate our seismic data from the inner to middle shelf with other seismic survey data from the surrounding shelf to indicate a relatively uniform underlying geology with no major boundaries. The seaward-dipping strata in seismic records from the inner Larsen A shelf (Fig. 4a) likely correspond to those observed by Sloan and others (1995) on the middle to outer shelf within Robertson Trough (seismic unit 2) and similar units further north of the study area in the James Ross Basin, which have the same dip angle $\left(3-5^{\circ}\right.$ in unit S5) (Anderson, 1992; Anderson and others, 1992; Smith and Anderson, 2009). The upper part of this unit was cored at site NBP0602A-3C to the northeast of James Ross Island during the recent SHALDRIL II cruise and showed evidence of fluvial-deltaic deposition during the late Eocene/early Oligocene, while the lowermost sedimentary strata of this unit have been interpreted as Late Cretaceous sedimentary rocks correlative to those cropping out on nearby Seymour Island (e.g. Feldmann and Woodburne, 1988). These rocks are relatively indurated, which explains why there is almost no penetration by the TOPAS and $3.5 \mathrm{kHz}$ signals on the inner shelf. As described by Sloan and others (1995), the dipping reflectors are continuous and evenly spaced, suggesting that these strata were uniformly deposited and are laterally homogeneous, as is typical of marine shelf deposits. Subglacial and glaciomarine strata generally display poorer seismic reflection continuity and are more laterally heterogeneous (Cooper and others, 1991; Anderson and others, 1992). Further out on the shelf within Robertson Trough, these sedimentary strata are overlain by a unit consisting of aggrading reflectors interpreted as glaciomarine and subglacial sediments deposited from fluctuating dynamic ice sheets during the Miocene to the Pleistocene (Sloan and others, 1995; Smith and Anderson 2009). The boundary between these units is defined by a change in dip angle as well as seismic facies (Sloan and others, 1995; Smith and Anderson, 2009), but this change was not observed on seismic line S103 (this study), where the dip angle is fairly consistent, and the older strata appear to be truncated at $<10 \mathrm{~m}$ below the sea-floor (Fig. 4a). A similar situation arises further north on the inner shelf, where $<5 \mathrm{~m}$ of Pleistocene glaciomarine and subglacial sediments overlie the late-Eocene/early-Oligocene dipping sedimentary strata (site NBP0602A-3C; Anderson and others, 2007). Aeromagnetic and aerogravity data have indicated an eastward thickening of the sedimentary succession on the NEAP shelf, from $3-4 \mathrm{~km}$ near the coast to $4-6 \mathrm{~km}$ at the shelf edge (LaBrecque and Ghidella, 1997). On seismic reflection profiles, the sedimentary strata are underlain by an acoustic basement thought to consist of indurated volcanic rocks of the Trinity Peninsula Group (Sloan and others, 1995), but the boundary between bedrock and sedimentary substrate is not observed on seismic line S103 (Fig. 4a). It has been suggested that this boundary between the volcanic rocks of the Antarctic Peninsula and sedimentary strata of the shelf is located further to the west in proximity to the current coastline (del Valle and others, 1992; Hathway, 2000; Gilbert and others, 2003). Thus, in line with previous interpretations, the seismic data collected in this study indicate a consistent and relatively uniform underlying geology on the inner to middle shelf. Ice flow velocity may have increased towards the shelf edge, but was not directly linked to geological boundaries.

\subsection{Associating the acoustically transparent layer with a soft deformation till}

Sediment cores from those parts of the trough displaying an ATL recovered a corresponding soft diamicton (unit 2), interpreted as a deformation till (Figs $3 \mathrm{a}$ and $\mathrm{b}$ and $7 \mathrm{c}$ and $\mathrm{d}$ ) (Pudsey and others, 2001; Evans and others, 2005). There are exceptions to this interpretation, where the ATL is related to (1) debris flow deposits on steep trough flanks (e.g. Larsen Inlet; Evans and others, 2005, fig. 11c), (2) iceberg turbates in areas where the TOPAS and $3.5 \mathrm{kHz}$ data show a rough surface reflector or the swath data reveal iceberg scours (e.g. 


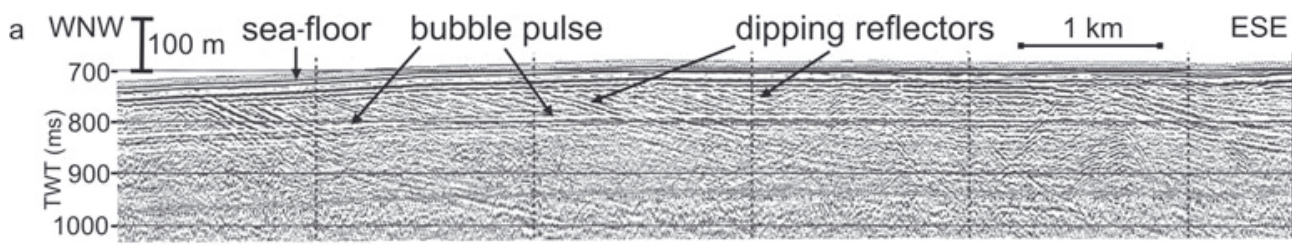

b
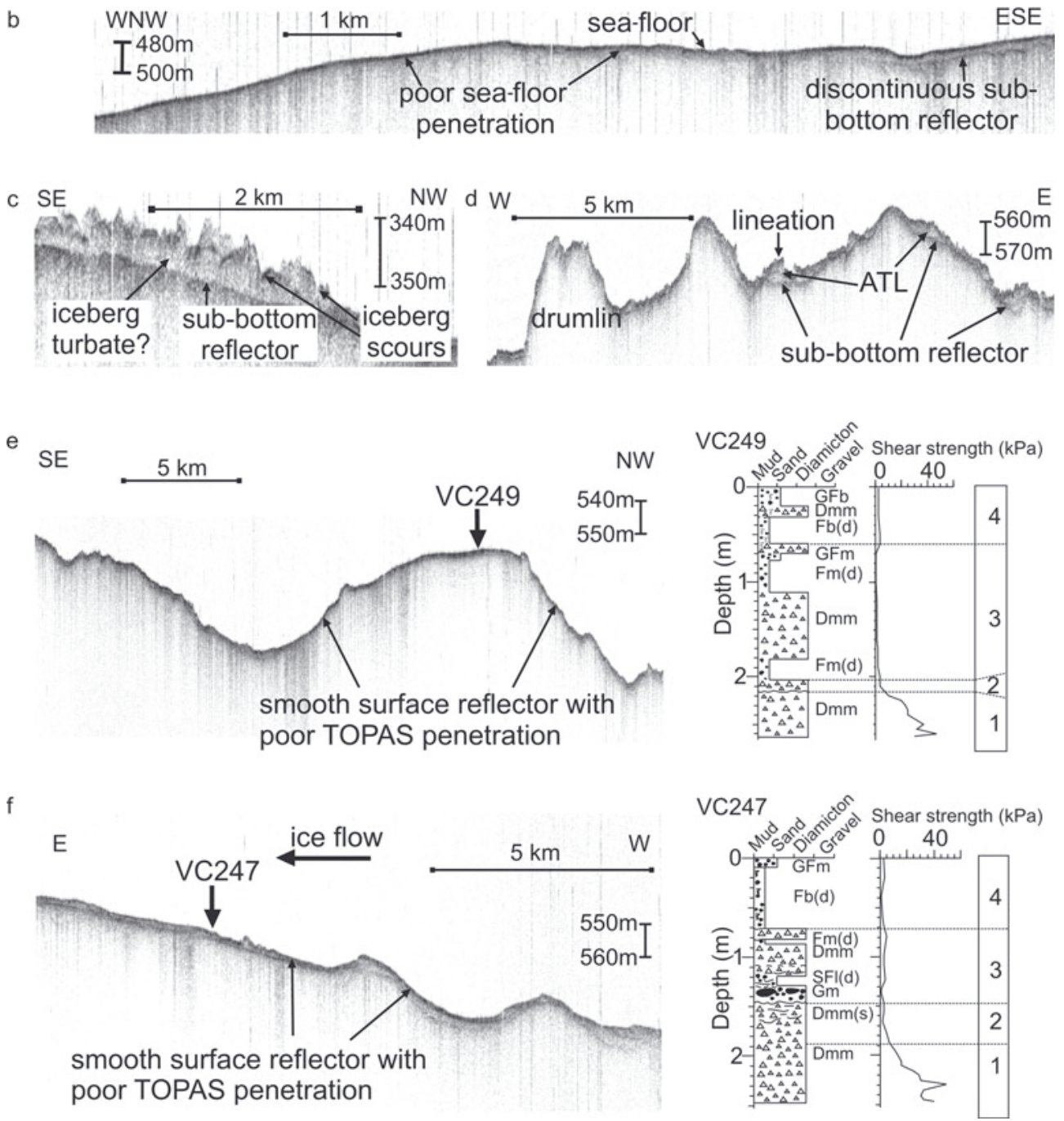

Fig. 4. (a) Part of single-channel seismic profile S103 from the Larsen A shelf, showing the apparent dip of the strata along the line of the profile is $2.5-6.5^{\circ}$. (TWT is two-way travel time.) See Figure 2 for location. (b) Corresponding TOPAS data collected along the same ship track as S103, showing a smooth sea-floor with little acoustic penetration. Locally, a weak, laterally discontinuous sub-bottom reflector is observed. Vertical scale bar indicates water depth $(\mathrm{m})$. (c) TOPAS profile with rough surface reflector. Swath bathymetric surveys from the area indicate that this part of the sea-floor has undergone iceberg scouring, and that the ATL may represent an iceberg turbate. (d) TOPAS profile is approximately transverse to former ice flow looking downstream. The large ridges are drumlins (recognizable on swath bathymetry data). The surface of the ATL is characterized by glacial lineations, which can be seen on swath data. (e) TOPAS data with corresponding core log for VC249. (f) TOPAS profile and corresponding core log for VC247.

at the mouth of Robertson Trough and in neighbouring shallow shelf areas; Fig. 4c), or (3) thick, postglacial glaciomarine sedimentary units (e.g. in Prince Gustav Channel) (Fig. 5a and b; Table 1; Pudsey and others, 2006). These types of sediments are included in the ATL, so it is not made up exclusively of soft till (areas indicated in green in Fig. 1). However, micromorphological analysis of sediments corresponding to the ATL performed by us (Reinardy and others, in press) indicates that most of the recovered soft diamictons are indeed soft tills or subglacial traction tills according to the classification of Evans and others (2006) (Fig. 3b).
If streaming ice flow occurred over the soft till, one would expect the ATL to be widespread within the glacial troughs. From the available TOPAS and $3.5 \mathrm{kHz}$ surveys, this appears to be the case on the middle to outer shelf, where $>2 \mathrm{~m}$ of soft till was recovered in sediment cores. On TOPAS profiles, however, the cored material corresponds to only the upper part of a thicker ATL (Figs 1, 3a and b and 7c and d). Evans and others (2005) noted that the thickness of the ATL in Robertson Trough is highly variable and ranges mainly from 1.5 to $8 \mathrm{~m}$, but is occasionally up to $15 \mathrm{~m}$ thick or locally absent. The distribution of till across the shelf within the troughs is likely to be the result of advection and accretion of 


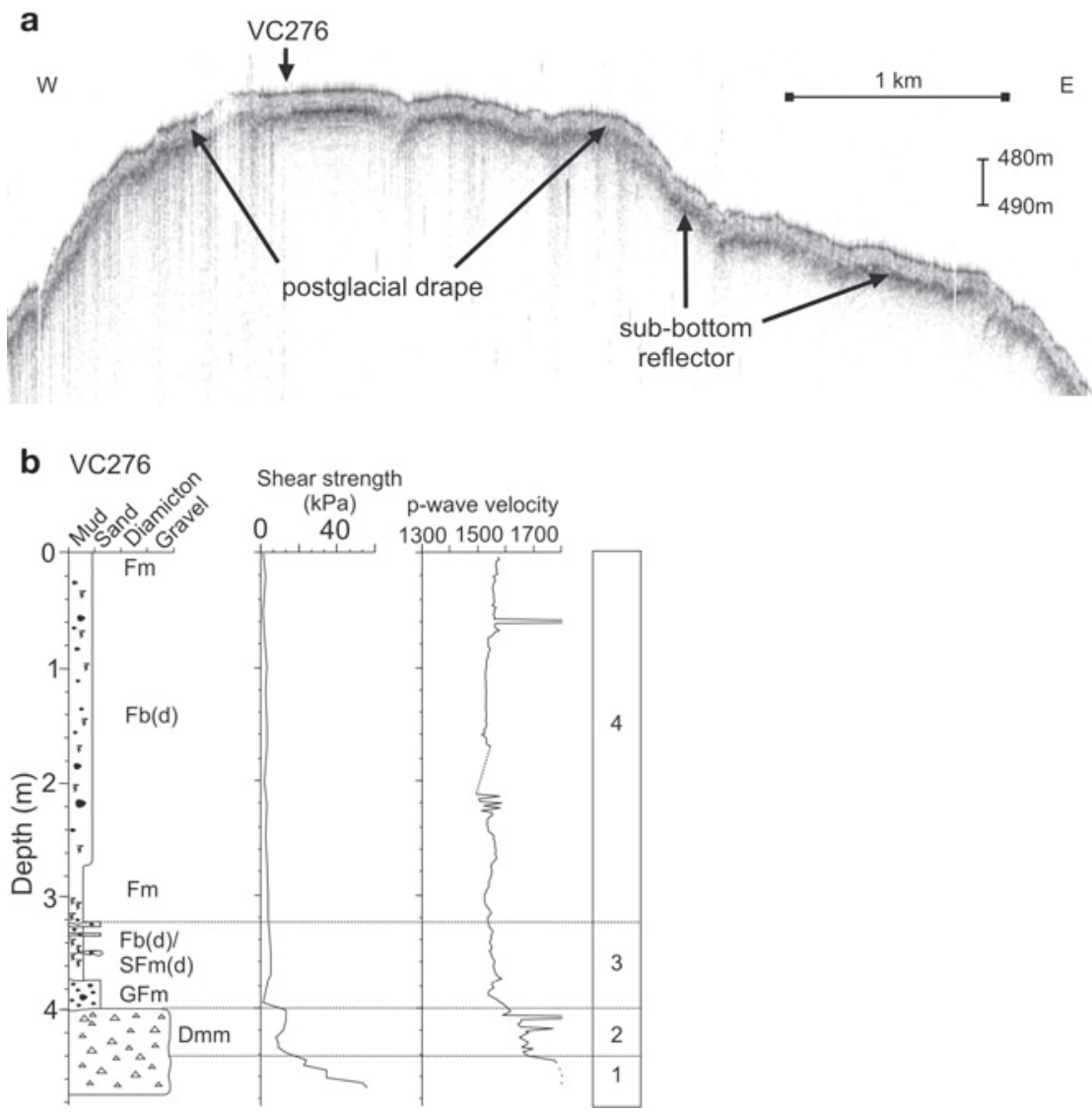

Fig. 5. (a) TOPAS profile from Prince Gustav Channel with location of VC276 (see Fig. 2 for location). Vertical scale bar indicates water depth (m). Nearly all of Prince Gustav Channel is underlain by a sub-bottom reflector, which is laterally continuous across the profile and corresponds to a thick postglacial drape recovered in sediment cores. (b) Core log of VC276 (after Evans and others, 2005). P-wave velocity is also shown; dashed line indicates erroneous values while p-wave velocity maxima are a result of cobbles/pebbles within the core. A sonic velocity of $1600 \mathrm{~m} \mathrm{~s}^{-1}$ was measured for unit 2 and assumed for soft till in other cores from the shelf.

soft till downstream during streaming ice flow (cf. Ó Cofaigh and others, 2007; Reinardy and others, in press).

On the inner Larsen A shelf, steep topography (e.g. on the western side of Greenpeace Trough) can lead to poor penetration of the TOPAS and $3.5 \mathrm{kHz}$ signals, and this may partly explain the relatively restricted presence of an ATL in this area. However, evidence from sediment cores also indicates only a very thin $(<0.4 \mathrm{~m})$ soft till layer on the inner shelf (Fig. 4e and f; Table 1). Both Pudsey and others (2001) and Evans and others (2005) noted the ATL is generally $\leq 5 \mathrm{~m}$ thick and laterally discontinuous on the inner shelf, corresponding to tills moulded into flutes or reworked by iceberg scouring and mass flows. Parts of the sea-floor lacking an ATL were interpreted as indicating the exposure of bedrock or poorly sorted subglacial sediments. Pudsey and others (2001) made these interpretations based on $3.5 \mathrm{kHz}$ data. However, in our study we used mainly TOPAS data that were digitally recorded and can be replayed at different scales, with processing and display parameters varied to enhance imaging of more subtle features. Thus, we are able to inspect in greater detail the initial TOPAS data collected from the inner shelf, which aids our interpretations of ice flow in this area.

Relatively little is known about the character of sea-floor sediments in the inner Robertson Trough, i.e. in the area previously occupied by the Larsen B ice shelf (west of $60^{\circ} \mathrm{W}$ ), where only a few swath tracks exist and only a few sediment cores were recovered (Domack and others, 2005;
Curry and Pudsey, 2007). However, the available data suggest similar conditions to those observed on the inner Larsen A shelf further north, with a thin and discontinuous ATL and only a thin $(<0.6 \mathrm{~m})$ soft till layer recovered in cores (Domack and others, 2005; Curry and Pudsey, 2007). To the south, on the northern flank of Jason Trough, the TOPAS and $3.5 \mathrm{kHz}$ data indicate an ATL and, by inference, the presence of a soft till, although the proximal part of the trough is still covered by the Larsen C ice shelf. A core from this area contained a soft till, although $<0.5 \mathrm{~m}$ of subglacial till was recovered (Curry and Pudsey, 2007).

\subsection{Basal sliding versus deformation of substrate}

Here we consider the relative proportions of basal sliding and sediment deformation from the inner to outer shelf. The ATL extent downstream within the troughs appears to reflect the distribution of the soft till. Due to the close lithological and petrological similarity between the soft and stiff tills (Reinardy and others, 2009) and evolution of polydeformational microstructures (Reinardy and others, in press), the soft till is interpreted as having been derived from the underlying stiff till as part of a deforming continuum (Ó Cofaigh and others, 2007). A modified model of fast flow within the troughs as indicated by Evans and others (2005) is presented here. In our model the deformation is not uniformly widespread across the entire icestream bed, but subglacial conditions vary spatially (and probably temporally) both within and between troughs, 

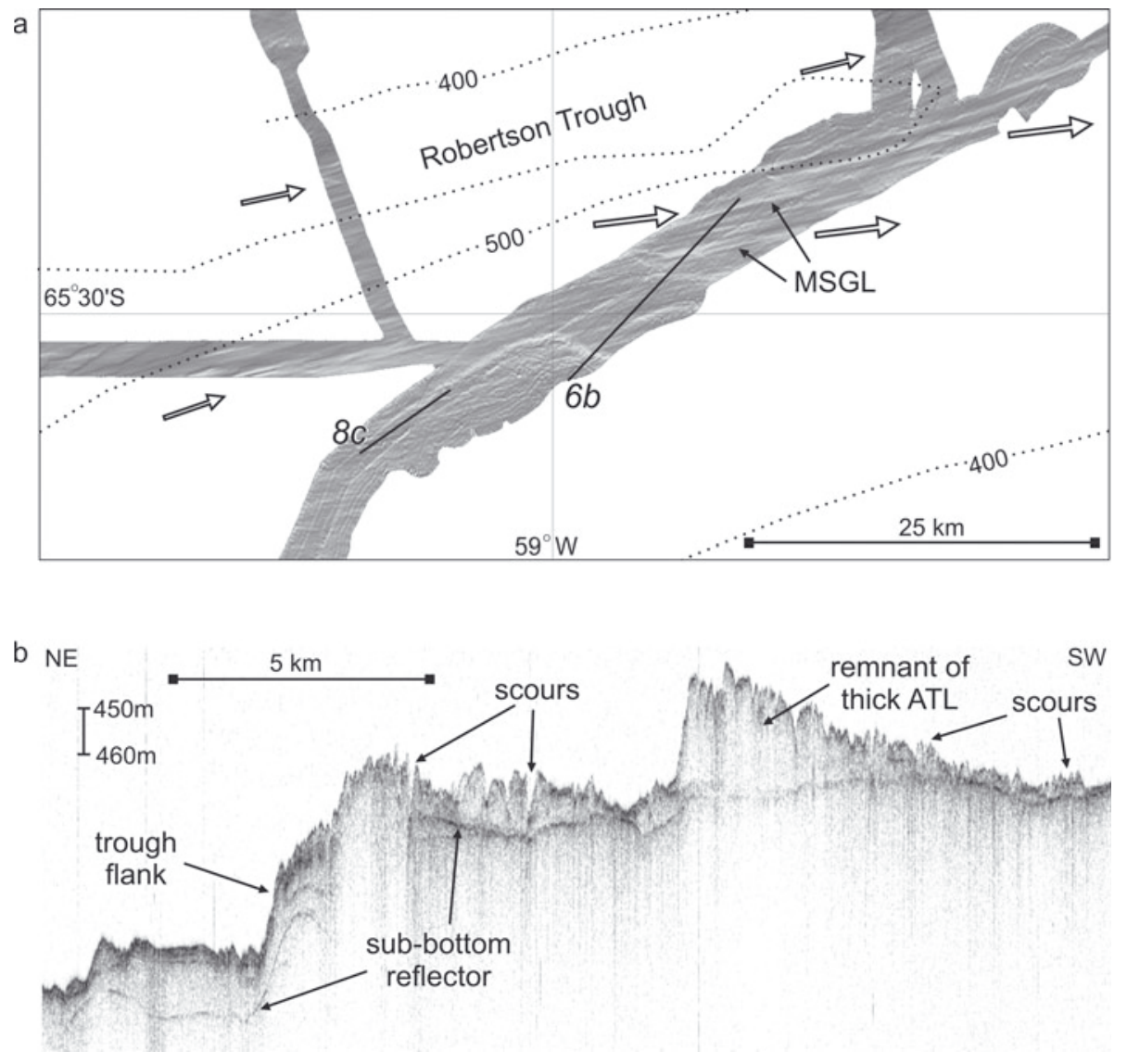

Fig. 6. (a) EM120 shaded relief image (gridcell size $50 \mathrm{~m} \times 50 \mathrm{~m}$ ), illuminated from the northwest, projected in Mercator (WGS84) modified from Evans and others (2005) from the inner to middle Robertson Trough, showing glacial lineations and MSGLs. Palaeo-ice flow (white arrows) and location on TOPAS profiles (black lines) indicated. (b) TOPAS profile is located oblique to former ice flow, and shows a remnant of a thick $(<21 \mathrm{~m})$ ATL that has been scoured on either side by icebergs. Vertical scale bar indicates water depth $(\mathrm{m})$.

which leads to local basal sliding as well as bed or substrate deformation (Fig. 8a and b). From the TOPAS and $3.5 \mathrm{kHz}$ data and sediment cores, it seems likely that subglacial till deformation was widespread within the outer Robertson Trough (although key to this interpretation is how MSGLs are formed; Ó Cofaigh and others, 2007). While there is only limited evidence of macroscale deformation from the sediment cores (Figs 3b and 7c and d) (Evans and others, 2005), microscale deformation is widespread within the soft tills (Reinardy and others, in press). Basal sliding is likely to have been more widespread within the onset zone of ice streaming in Greenpeace Trough (compared with the outer shelf), where the ATL and thus soft deformation till are thin or even absent (Fig. $4 b$ and $d-f$ ).

We interpret basal sliding as having occurred over stable areas of the bed composed either of bedrock or a relatively thin $(<10 \mathrm{~m}$ on the inner shelf) stiff till layer which would have provided only a limited source of soft till. Once present, the soft till would have been advected downstream (Fig. 8b). It should be noted that the lack of an ATL does not necessarily mean that the sea-floor lacks a soft till. Thin $(<0.5 \mathrm{~m})$ sediment layers may be below the resolution of the TOPAS and $3.5 \mathrm{kHz}$ data. However, almost all the sediment cores that recovered a soft till were taken from sites with an ATL (Figs $3 a$ and $b$ and $7 c$ and $d$ ), while cores from shallower shelf areas without an ATL only recovered a stiff till beneath postglacial sediments. Localized sliding is likely to have been most common on the inner shelf, where the sea-floor reflector appears very hard in the TOPAS and
$3.5 \mathrm{kHz}$ data and a majority of the sediment cores recovered $<0.4 \mathrm{~m}$ of soft till (Fig. $4 \mathrm{e}$ and $\mathrm{f}$ ). The lack of TOPAS and $3.5 \mathrm{kHz}$ penetration and evidence of the underlying dipping Mesozoic-Palaeogene strata within $10 \mathrm{~m}$ of the sea-floor in the seismic line suggest that some parts of the trough bed may have been more stable and less likely to deform under the shear stress exerted by the palaeo-ice stream (Fig. 4a and b).

Sedimentary characteristics observed in areas of basal sliding beneath other Quaternary ice sheets have included sorted sediment layers and the preservation of small-scale primary sedimentary structures (Piotrowski and others, 2001, 2004, 2006). None of these features was observed in the cores from the NEAP shelf, although there are rare situations where sharp contacts exist between tills (e.g. VC325 and VC340; Evans and others 2005, fig. 13c and f), the tills appear stratified (e.g. VC247; Evans and others 2005, figs $4 \mathrm{f}$ and $15 \mathrm{a}$ and table 1 ) or shells have been preserved in the tills (Reinardy, 2010). However, even in areas of basal sliding, thin layers $(<0.5 \mathrm{~m})$ of deformation till may be found, as both processes are transient in space and time (cf. Piotrowski and others, 2004, 2006). Soft till layers of $<0.4 \mathrm{~m}$ thickness were recovered in several cores from the inner shelf (Evans and others, 2005) and this could explain why some of the aforementioned features have not been preserved at the surface of the stiff till layer (Fig. 4e and f).

The TOPAS and $3.5 \mathrm{kHz}$ data from the NEAP shelf indicate that areas with a thick ATL and without an ATL can occur relatively close together (Fig. 8c). In Robertson 

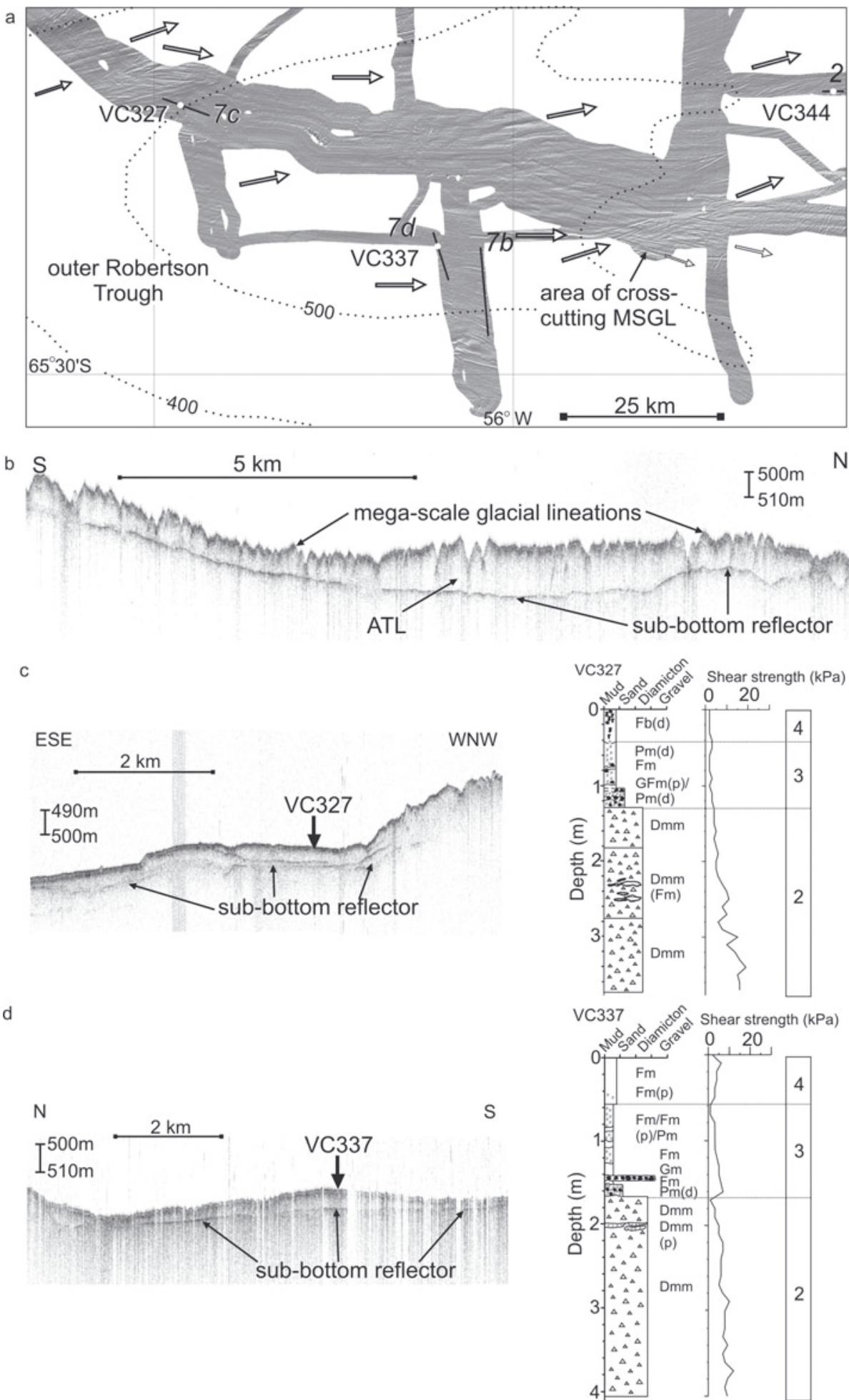

Fig. 7. (a) EM120 shaded relief image (gridcell size $50 \mathrm{~m} \times 50 \mathrm{~m}$ ), illuminated from the north, projected in Mercator (WGS84) showing MSGLs, with some areas of cross-cutting MSGLs. Black lines indicate location of TOPAS profiles, and white dots indicate core locations. (b) TOPAS profile runs on the southern side of the trough transverse to former ice flow (looking upstream) and indicates a 10-15 m thick ATL. MSGLs are formed on the surface reflector and can also be seen in swath bathymetric surveys (above). Vertical scale bar indicates water depth (m). (c) TOPAS profile and corresponding core log of VC327. (d) TOPAS profile and corresponding core log of VC337.

Trough the boundary is sometimes parallel to the palaeo-icestream flow direction, forming 'fingers' of sediment down the trough axis (Fig. 1). This may be due to the migration of the boundary as the soft till is advected down-flow, similar to the deforming-sliding boundary at the base of Rutford Ice Stream (Smith and Murray, 2009). The ATL rarely pinches out, but rather terminates abruptly where the surface reflector merges with the sub-bottom reflector (Fig. 8c) Occasionally the sub-bottom reflector is laterally discontinuous even over a small $\left(<1 \mathrm{~km}^{2}\right)$ area (Figs 1 and $4 \mathrm{~b}$ and $\left.\mathrm{d}\right)$. It is likely that locally the extent of the soft till layer within a certain area continually changed as different parts of the bed and the underlying stiff till became reworked and advected downstream. 

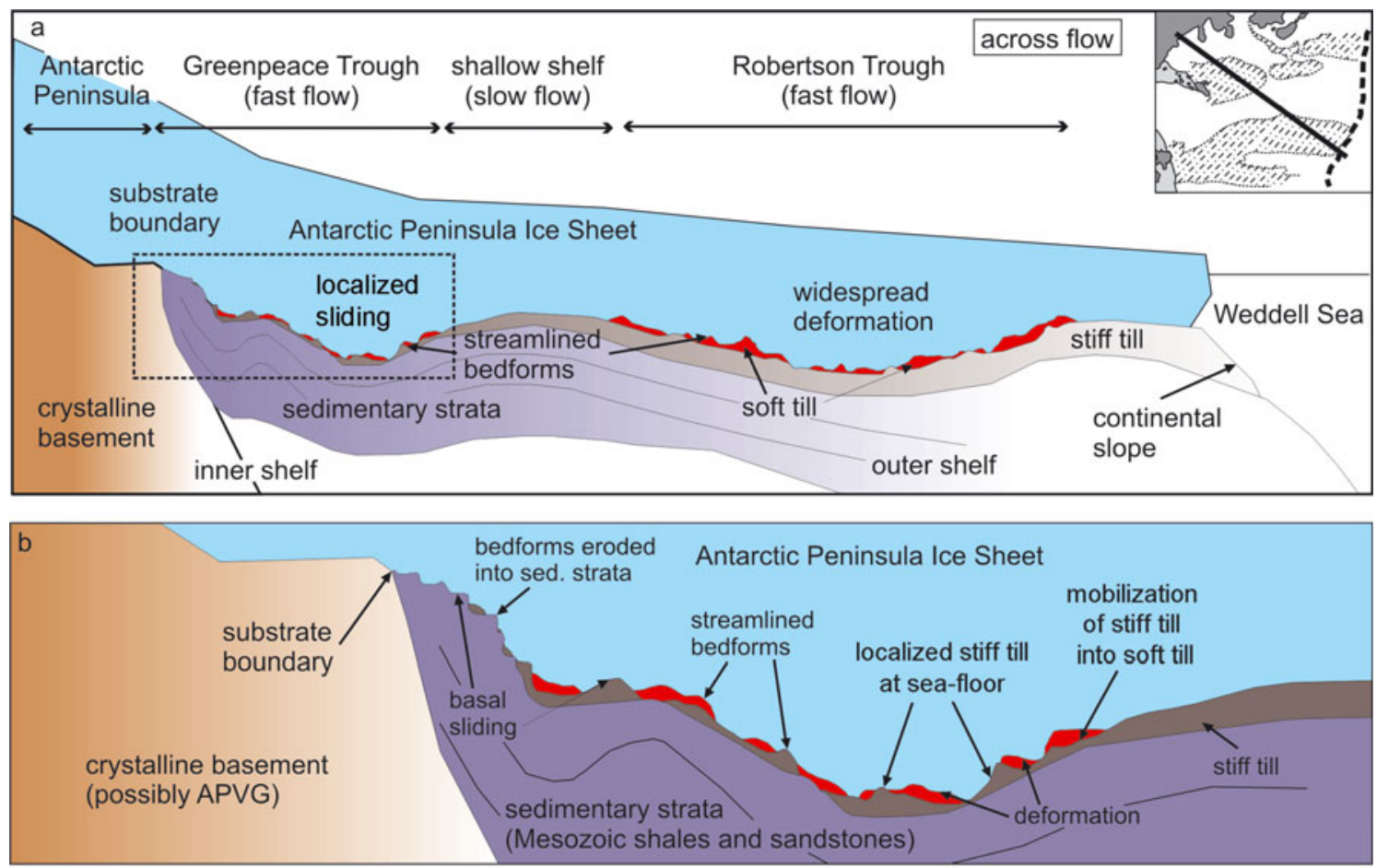

C

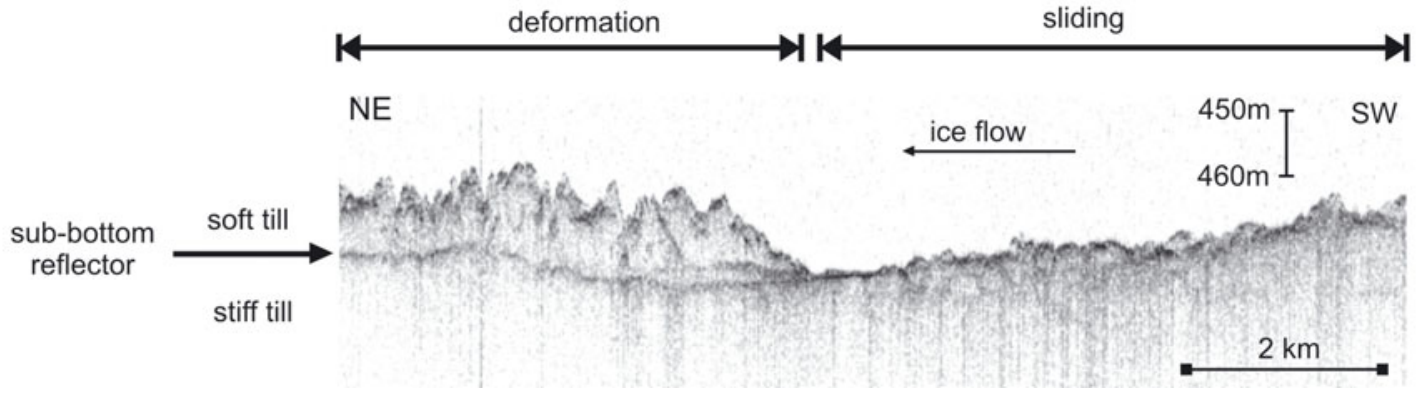

Fig. 8. (a) Schematic diagram of ice flow over the Larsen shelf in Greenpeace and Robertson Troughs (not to scale), indicating basal conditions and underlying substrate during the last glacial period. Inset indicates cross section in relation to the NEAP shelf (solid black line) and shelf break (dashed black line). Black rectangle indicates location of (b) below, which shows a detailed schematic diagram of the basal conditions within Greenpeace Trough on the inner Larsen A shelf during the last glacial period. (c) TOPAS profile located within Robertson Trough on the inner to middle shelf (see Fig. 6a for location). Vertical scale bar indicates water depth (m). Profile is located roughly parallel to former ice flow and shows the sharp boundary between an area of the sea-floor underlain by an ATL corresponding to a soft till and interpreted as indicating subglacial deformation, and an area lacking an ATL and interpreted as being underlain by stiff till possibly with a very thin soft till layer where basal sliding took place.

Even on the outer shelf, limited basal sliding may have taken place (Fig. 8a). The presence of MSGLs on the outer shelf may only indicate local deformation (cf. Clark and others, 2003). Heroy and Anderson (2005) interpreted up to four sets of MSGLs representing changes of former ice flow in the outer Robertson Trough (Fig. 7a) (cf. Evans and others, 2005). The preservation of these cross-cutting features within an ATL $>5$ m thick (Fig. 1) is difficult to envisage on an icestream bed composed entirely of a continually deforming sediment layer. It certainly suggests that in localized areas of the ice-stream bed there must have been little erosion or deposition over the course of the different flow events, otherwise the record of older palaeo-flow events would have been erased or buried.

The interpretation of the stiff and soft tills representing sliding and deformation (Fig. 8c), respectively, along the beds of palaeo-ice streams on the NEAP shelf is consistent with the idea of subglacial beds as a mosaic of deforming and stable spots (cf. Piotrowski and others, 2004). However, there is more of a geographic pattern within cross-shelf troughs in the study area, with basal sliding dominating on the inner shelf and deformation (as indicated by the presence of an ATL that corresponds to the soft till) being more widespread on the outer shelf. The same pattern was inferred by Smith (1997a,b) and Smith and Murray (2009) from seismic surveys on the modern Rutford Ice Stream, which indicated that three-quarters of the bed was underlain by saturated, deforming sediment and the extent of this sediment increased downstream. Models of basal conditions for Pine Island and Thwaites Glaciers also suggest that both have 'mixed' bed conditions, with extensive areas of both bedrock and weak till (Joughin and others, 2009). Research into a tributary of Bindschadler Ice Stream, Siple Coast, also suggests that variable basal conditions result in a 'patchwork' pattern, with areas of stiff diamicton alternating with areas of soft diamicton (termed 'wet till') (Peters and others, 2007). We consider that the results presented here indicate palaeo-ice streams draining the eastern margin of the APIS 


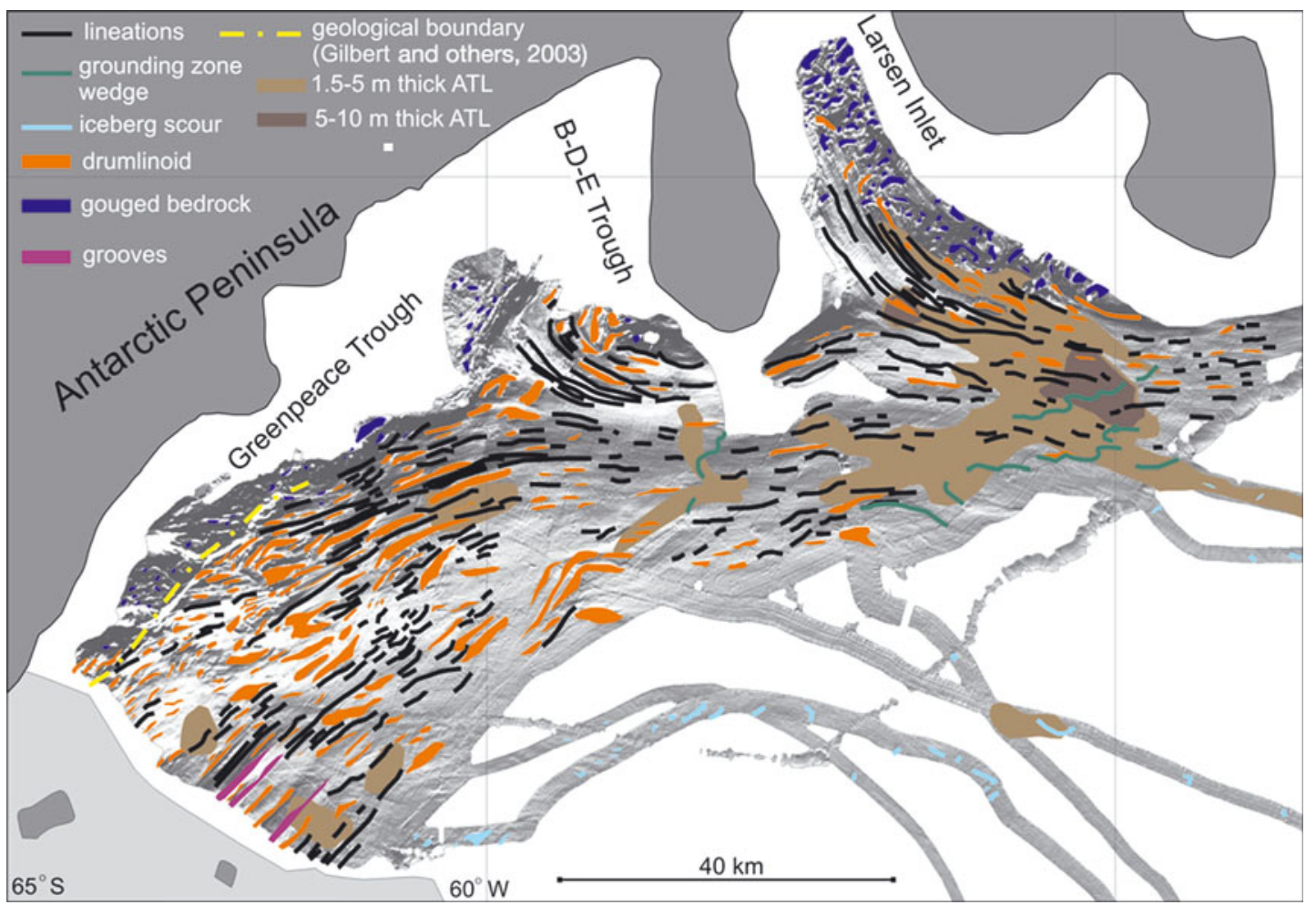

Fig. 9. Geomorphic map of Greenpeace Trough on the inner NEAP shelf. Subglacial features digitized from $50 \mathrm{~m}$ swath bathymetric grids taken from Evans and others (2005). See Figure 2 for swath bathymetry without annotation. Also included is the thickness of the ATL calculated from TOPAS and $3.5 \mathrm{kHz}$ data.

across the NEAP shelf may have had a similar basal regime (Fig. 8a and b).

\subsection{Change in the dominant palaeo-ice flow mechanism contributes to evolution of bedforms from the inner to outer shelf}

The assemblage of subglacial bedforms across the NEAP shelf points to a complex basal regime. The locations of the palaeo-ice streams that drained the eastern side of the APIS were apparently topographically controlled. The inner shelf, including Larsen Inlet, B-D-E and Greenpeace troughs, has been interpreted as the palaeo-onset zone of streaming ice flow (Fig. 2) (Evans and others, 2005). The increase in elongation values of bedforms and change from drumlins, mega-flutes and lineations on the inner shelf to MSGLs on the outer shelf is in agreement with a generalized model of bedform evolution within other cross-shelf troughs on the West Antarctic shelf (e.g. Wellner and others, 2001, 2006). This model, however, suggests that bedform assemblages are highly dependent on a change in substrate geology across the continental shelf, which also controlled increasing ice flow velocity from an onset zone on the inner shelf towards an ice margin on the outer shelf. However, the geological substrate of the NEAP shelf is less varied than on many other parts of the Antarctic shelf (Hathway, 2000; Reinardy and others, 2009). The only significant geological boundary occurs at the very head of Greenpeace Trough, which may be underlain by crystalline volcanic rocks cropping out along the Nordenskjold Coast (Gilbert and others, 2003).

The gradual increase in elongation ratio for bedforms from the inner to outer shelf (Evans and others, 2005) is likely to have been caused by increasing ice flow velocity downstream. However, this change in velocity cannot fully explain the evolution of bedforms locally across the shelf. Both erosional and depositional landforms (e.g. drumlins, lineations, gouged bedrock, large-scale grooves, grounding zone wedges, flutes and mega-flutes) are observed in close spatial association within the relatively confined Greenpeace Trough (Fig. 9). The seismic line, S103, from the inner shelf indicates that Mesozoic-Palaeogene sedimentary rocks are truncated at relatively shallow depth beneath the seabed (Fig. 4a), while sediment cores from across the shelf recovered tills sourced from these rocks (Reinardy and others, 2009). Any bedforms eroded into this relatively hard substrate will have a higher preservation potential, and this could partly explain the complex set of landforms preserved on the inner shelf. The complex bedform assemblage on the inner shelf is in stark contrast to the outer shelf, where a far more restricted set of landforms is observed, mainly MSGLs (Fig. 7a and b). TOPAS data have been used to show that most of these MSGLs are formed in the ATL, corresponding to the thick soft till layers recovered in sediment cores from the middle to outer shelf (Pudsey and others, 2001; Evans and others, 2005; Heroy and Anderson, 2005).

The generalized model of bedform evolution proposed by Wellner and others (2001, 2006) does not show this complexity in the onset zone of streaming flow because it only takes into account a direct relation between bedform elongation and flow velocity (e.g. Wellner and others, 2001, fig. 7), with flow velocity in turn being controlled by substrate. What is not recognized is that the nature of the substrate also affects bedforms directly, as indicated within Greenpeace Trough, so that accelerating flow over a complex bed (e.g. patches of exposed crystalline bedrock, 
stiff till and soft till) produces a highly varied bedform assemblage (Fig. 9). Our findings are in agreement with more recent work from the West Antarctic shelf that indicates that streaming flow can occur over hard substrate (crystalline rock or stiff till) and that substrate transition or geological boundaries do not necessarily control the position of the streaming onset zone (Graham and others, 2009; Larter and others, 2009). Studies in other regions have also found that subglacial geology had limited or no apparent control on palaeo-ice-stream dynamics (Stokes and Clark, 2003). However, it is important to point out that the data presented here do not necessarily refute previous models in terms of ice-sheet dynamics. Although the inner shelf geomorphology is more complex, it was still ultimately an area of increasing ice flow velocity, with MSGLs dominating further down-flow across the outer shelf.

It seems likely that part of this evolution of bedforms was actually driven by the changes in the dominant processes facilitating streaming flow. On the inner shelf it is likely that the bed had been more stable with basal sliding dominating, and bedforms eroded into the stiff till or bedrock having a high preservation potential (cf. Graham and others, 2009). In contrast, the bed on the outer shelf contains more porous soft tills that likely had been continually deforming. In our study area, bedforms are likely to have been continually formed and eroded, as has been observed under contemporary ice streams (Smith and others, 2007).

\section{CONCLUSIONS}

Combining geophysical and sedimentological data from cores recovered on the NEAP shelf has indicated complex basal conditions below palaeo-ice streams that drained the APIS, when it extended to the shelf edge during the last glacial period:

TOPAS and $3.5 \mathrm{kHz}$ surveys on the NEAP shelf indicate the localized presence of an ATL on the inner shelf becoming more widespread and thicker within crossshelf troughs on the middle to outer shelf.

Sediment cores recovered from parts of the sea-floor underlain by an ATL have recovered a corresponding soft deformation till, while in areas lacking an ATL a stiff till, or a stiff till with only a very thin $(<0.4 \mathrm{~m})$ overlying soft till layer, was recovered.

Much of the sea-floor on the inner shelf is underlain by bedrock or a stiff till representing more stable areas of the ice-stream bed. This substrate will favour basal sliding, in contrast to the parts of the troughs on the middle and outer shelf. In these latter areas, thick soft till sequences are observed, indicating that deformation was the dominant basal process.

The distribution of till units within the troughs is due to soft till being advected downstream.

The downstream transition of basal sliding to subglacial deformation as well as the downstream increase of iceflow velocity is manifest in the geomorphic imprint from the inner to outer shelf. In particular, the onset zone of streaming ice flow is characterized by a far more complex set of bedforms than previous models have suggested.

\section{ACKNOWLEDGEMENTS}

This work forms a contribution to the Ice Sheets component of the British Antarctic Survey Polar Science for Planet Earth Programme. It was funded by the UK Natural Environment Research Council. We thank the officers and crew of RRS James Clark Ross for their skilful ice navigation, the British Geological Survey team for coring in Antarctic conditions during cruises JR48 and JR71 to the NEAP continental shelf in 2000 and 2002, and especially C. Pudsey, J. Evans and A. Graham for all their help.

\section{REFERENCES}

Alley, R.B., D.D. Blankenship, C.R. Bentley and S.T. Rooney. 1986. Deformation of till beneath Ice Stream B, West Antarctica. Nature, 322(6074), 57-59.

Anderson, J.B. 1992. Preliminary results of high-resolution seismic and coring surveys in the Antarctic Peninsula region. Antarct. J. US, 26(5), 123-126.

Anderson, J.B. and L. Oakes-Fretwell. 2008. Geomorphology of the onset area of a paleo-ice stream, Marguerite Bay, Antarctic Peninsula. Earth Surf. Process. Landf., 33(4), 503-512.

Anderson, J.B., S.S. Shipp and F.P. Siringan. 1992. Preliminary seismic stratigraphy of the northwestern Weddell Sea continental shelf. In Yoshida, Y., K. Kaminuma and K. Shiraishi, eds. Recent progress in Antarctic earth science. Proceedings of the Sixth International Symposium on Antarctic Earth Sciences, 9-13 September 1991, Saitama, Japan. Tokyo, Terra Scientific Publishing, 603-612.

Anderson, J.B. and 7 others. 2007. Seismic and chronostratigraphic results from SHALDRIL II, northwestern Weddell Sea. USGS Open File Rep. 2007-1047, Short Research Paper 094.

Bennett, M.R. 2003. Ice streams as the arteries of an ice sheet: their mechanics, stability and significance. Earth-Sci. Rev., 61(3-4), 309-339.

Bentley, C.R. 1987. Antarctic ice streams: a review. J. Geophys. Res., 92(B9), 8843-8858.

Bindschadler, R.A., M.A. Fahnestock, P. Skvarca and T.A. Scambos. 1994. Surface-velocity field of the northern Larsen Ice Shelf, Antarctica. Ann. Glaciol., 20, 319-326.

Blankenship, D.D., C.R. Bentley, S.T. Rooney and R.B. Alley. 1986. Seismic measurements reveal a saturated porous layer beneath an active Antarctic ice stream. Nature, 322(6074), 54-57.

Camerlenghi, A. and 7 others. 2001. Glacial morphology and postglacial contourites in northern Prince Gustav Channel (NW Weddell Sea, Antarctica). Mar. Geophys. Res., 22(5-6), 417-443.

Canals, M., R. Urgeles and A.M. Calafat. 2000. Deep sea-floor evidence of past ice streams off the Antarctic Peninsula. Geology, 28(1), 31-34.

Clark, C.D., S.M. Tulaczyk, C.R. Stokes and M. Canals. 2003. A groove-ploughing theory for the production of mega-scale glacial lineations, and implications for ice-stream mechanics. J. Glaciol., 49(165), 240-256.

Cook, A.J. and D.G. Vaughan. 2010. Overview of areal changes of the ice shelves on the Antarctic Peninsula over the past 50 years. Cryosphere, 4(1), 77-98.

Cooper, A.K., P.J. Barrett, K. Hinz, V. Traube, G. Leitchenkov and H.M.J. Stagg. 1991. Cenozoic prograding sequences of the Antarctic continental margin: a record of glacioeustatic and tectonic events. Mar. Geol., 102(1-4), 175-213.

Curry, P. and C.J. Pudsey. 2007. New Quaternary sedimentary records from near the Larsen $\mathrm{C}$ and former Larsen $\mathrm{B}$ ice shelves; evidence for Holocene stability. Antarct. Sci., 19(3), 355-364.

Del Valle, R.A., D.H. Elliot and D.I.M. Macdonald. 1992. Sedimentary basins on the east flank of the Antarctic Peninsula: proposed nomenclature. Antarct. Sci., 4(4), 477-478.

Del Valle, R.A., J.C. Lusky and R. Roura. 1998. Glacial trough under the Larsen Ice Shelf, Antarctic Peninsula. Antarct. Sci., 10(2), 173-174. 
Domack, E. and 9 others. 2005. Stability of the Larsen B ice shelf on the Antarctic Peninsula during the Holocene epoch. Nature, 436(7051), 681-685.

Engelhardt, H. and B. Kamb. 1998. Basal sliding of Ice Stream B, West Antarctica. J. Glaciol., 44(147), 223-230.

Engelhardt, H., N. Humphrey, B. Kamb and M. Fahnestock. 1990. Physical conditions at the base of a fast moving Antarctic ice stream. Science, 248(4951), 57-59.

Evans, D.J.A., E.R. Phillips, J.F. Hiemstra and C.A. Auton. 2006. Subglacial till: formation, sedimentary characteristics and classification. Earth-Sci. Rev., 78(1-2), 115-176.

Evans, J., C.J. Pudsey, C. Ó Cofaigh, P. Morris and E. Domack. 2005. Late Quaternary glacial history, flow dynamics and sedimentation along the eastern margin of the Antarctic Peninsula ice sheet. Quat. Sci. Rev., 24(5-6), 741-774.

Eyles, N., C.H. Eyles and A. Miall. 1983. Lithofacies types and vertical profile models: an alternative approach to the description and environmental interpretation of glacial diamict and diamictite sequences. Sedimentology, 30(3), 393-410.

Feldmann, R.M. and M.O. Woodburne. 1988. Geology and paleontology of Seymour Island, Antarctic Peninsula. Geol. Soc. Am. Mem. 169.

Gilbert, R., E.W. Domack and A. Camerlenghi. 2003. Deglacial history of the Greenpeace Trough: ice sheet to ice shelf transition in the Northwestern Weddell Sea. In Domack, E., A. Leventer, A. Burnett, R. Bindschadler, P. Convey and M. Kirby, eds. Antarctic Peninsula climate variability: historical and paleoenvironmental perspectives. Washington, DC, American Geophysical Union. (Antarctic Research Series 79.)

Graham, A.G.C., R.D. Larter, K. Gohl, C.-D. Hillenbrand, J.A. Smith and G. Kuhn. 2009. Bedform signature of a West Antarctic palaeo-ice stream reveals a multi-temporal record of flow and substrate control. Quat. Sci. Rev., 28(25-26), 2774-2793.

Hathway, B. 2000. Continental rift to back-arc basin: Jurassic-Cretaceous stratigraphical and structural evolution of the Larsen Basin, Antarctic Peninsula. J. Geol. Soc. London, 157(2), 417-432.

Heroy, D.C. and J.B. Anderson. 2005. Ice-sheet extent of the Antarctic Peninsula region during the Last Glacial Maximum (LGM): insights from glacial geomorphology. Geol. Soc. Am. Bull., 117(11-12), 1497-1512.

Joughin, I. and 6 others. 2009. Basal conditions for Pine Island and Thwaites Glaciers, West Antarctica, determined using satellite and airborne data. J. Glaciol., 55(190), 245-257.

Kamb, B. 2001. Basal zone of the West Antarctic ice streams and its role in lubrication of their rapid motion. In Alley, R.B. and R.A. Bindschadler, eds. The West Antarctic ice sheet: behavior and environment. Washington, DC, American Geophysical Union, 157-199. (Antarctic Research Series 77.)

LaBrecque, J.L. and M.E. Ghidella. 1997. Bathymetry, depth to magnetic basement, and sediment thickness estimates from aerogeophysical data over the western Weddell Basin. J. Geophys. Res., 102(B4), 7929-7945.

Larter, R.D. and P.F. Barker. 1989. Seismic stratigraphy of the Antarctic Peninsula Pacific margin: a record of Pliocene-Pleistocene ice volume and paleoclimate. Geology, 17(8), 731-734.

Larter, R.D. and L.E. Vanneste. 1995. Relict subglacial deltas on the Antarctic Peninsula outer shelf. Geology, 23(1), 33-36.

Larter, R.D. and 8 others. 2009. Subglacial bedforms reveal complex basal regime in a zone of paleo-ice stream convergence, Amundsen Sea embayment, West Antarctica. Geology, 37(5), 411-414.

Ó Cofaigh, C. and 6 others. 2005. Flow dynamics and till genesis associated with a marine-based Antarctic palaeo-ice stream. Quat. Sci. Rev., 24(5-6), 709-740.

Ó Cofaigh, C., J. Evans, J.A. Dowdeswell and R.D. Larter. 2007. Till characteristics, genesis and transport beneath Antarctic paleoice streams. J. Geophys. Res., 112(F3), F03006. (10.1029/ 2006JF000606.)
Peters, L.E., S. Anandakrishnan, R.B. Alley and A.M. Smith. 2007. Extensive storage of basal meltwater in the onset region of a major West Antarctic ice stream. Geology, 35(3), 251-254.

Piotrowski, J.A., D.M. Mickelson, S. Tulaczyk, D. Krzyszkowski and F.W. Junge. 2001. Were deforming subglacial beds beneath past ice sheets really widespread? Quat. Int., 86(1), 139-150.

Piotrowski, J.A., N.K. Larsen and F.W. Junge. 2004. Reflections on soft subglacial beds as a mosaic of deforming and stable spots. Quat. Sci. Rev., 23(9-10), 993-1000.

Piotrowski, J.A., N.K. Larsen, J. Menzies and W. Wysota. 2006. Formation of subglacial till under transient bed conditions: deposition, deformation, and basal decoupling under a Weichselian ice sheet lobe, central Poland. Sedimentology, 53(1), 83-106

Pudsey, C.J., J. Evans, E.W. Domack, P. Morris and R.A. del Valle. 2001. Bathymetry and acoustic facies beneath the former Larsen-A and Prince Gustav ice shelves, north-west Weddell Sea. Antarct. Sci., 13(3), 312-322.

Pudsey, C.J., J.W. Murray, P. Appleby and J. Evans. 2006. Ice shelf history from petrographic and foraminiferal evidence, Northeast Antarctic Peninsula. Quat. Sci. Rev., 25(17-18), 2357-2379.

Reinardy, B.T.I. 2010. The dynamics of palaeo-ice streams draining the eastern margin of the Antarctic Peninsula Ice Sheet during the late Quaternary. (PhD thesis, University of Wales.)

Reinardy, B.T.I., C.J. Pudsey, C.-D. Hillenbrand, T. Murray and J. Evans. 2009. Contrasting sources for glacial and interglacial shelf sediments used to interpret changing ice flow directions in the Larsen Basin, Northern Antarctic Peninsula. Mar. Geol., 266(1-4), 156-171.

Reinardy, B.T.I., J.F. Hiemstra, T. Murray, C.-D. Hillenbrand and R.D. Larter. In press. Till genesis at the bed of an Antarctic Peninsula palaeo-ice stream as indicated by micromorphological analysis. Boreas. (10.1111/j.1502-3885.2010.00199.x.)

Sloan, B.J., L.A. Lawver and J.B. Anderson. 1995. Seismic stratigraphy of the Larsen Basin, eastern Antarctic Basin Peninsula. In Cooper, A.K., P.F. Barker and G. Brancolini, eds. Geology and seismic stratigraphy of the Antarctic margin. Washington, DC, American Geophysical Union, 59-74. (Antarctic Research Series 68.)

Smith, A.M. 1997a. Basal conditions on Rutford Ice Stream, West Antarctica from seismic observations. J. Geophys. Res., 102(B1), 543-552.

Smith, A.M. 1997b. Variations in basal conditions on Rutford Ice Stream, West Antarctica. J. Glaciol., 43(144), 251-261.

Smith, A.M. and T. Murray. 2009. Bedform topography and basal conditions beneath a fast-flowing West Antarctic ice stream. Quat. Sci. Rev., 28(7-8), 584-596.

Smith, A.M. and 6 others. 2007. Rapid erosion, drumlin formation and changing hydrology beneath an Antarctic ice stream. Geology, 35(2), 127-130.

Smith, R.T. and J.B. Anderson. 2009. Ice-sheet evolution in James Ross Basin, Weddell Sea margin of the Antarctic Peninsula: the seismic stratigraphic record. Geol. Soc. Am. Bull., 122(5-6), 830-842.

Stokes, C.R. and C.D. Clark. 2001. Palaeo-ice streams. Quat. Sci. Rev., 20(13), 1437-1457.

Stokes, C.R. and C.D. Clark. 2003. Laurentide ice streaming on the Canadian Shield: a conflict with the sift-bedded ice stream paradigm? Geology, 31(4), 347-350.

Wellner, J.S., A.L. Lowe, S.S. Shipp and J.B. Anderson. 2001. Distribution of glacial geomorphic features on the Antarctic continental shelf and correlation with substrate: implications for ice behavior. J. Glaciol., 47(158), 397-411.

Wellner, J.S., D.C. Heroy and J.B. Anderson. 2006. The death mask of the Antarctic ice sheet: comparison of glacial geomorphic features across the continental shelf. Geomorphology, 75(1-2), 157-171. 